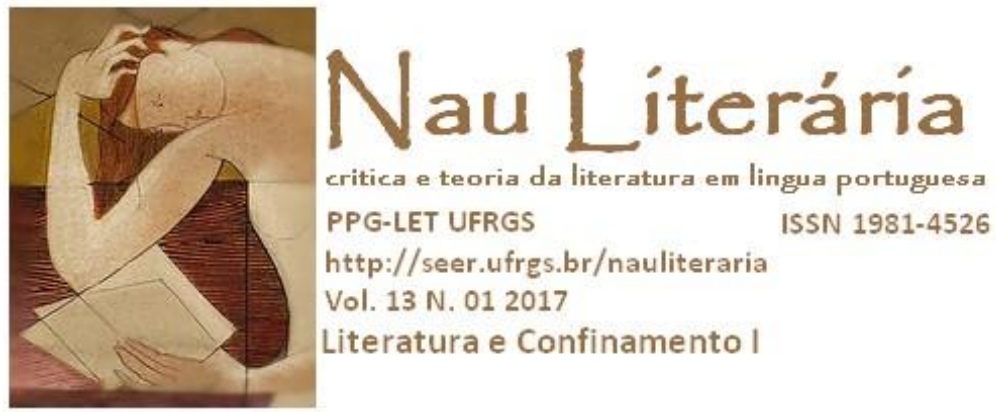

\title{
Ali, longe de onde a vista ou os ouvidos alcançam: sobre loucura e literatura da urgência em Lima Barreto, Maura Lopes Cançado, e Stela do Patrocínio
}

\author{
Rosângela Lopes da Silva
}

\begin{abstract}
Resumo:
Aportado em uma abordagem foucaultiana, este estudo analisa a relação palavra e silêncio e a urgência da escrita, defendida por Luciana Hidalgo como singular às escritas de si que nascem no confinamento, nas narrativas Diário do Hospício (1956), de Lima Barreto (1881-1922), Hospício é Deus: diário I (1965), de Maura Lopes Cançado (1929-1993) e Reino dos Bichos e dos animais é o meu nome (2001), de Stela do Patrocínio (1941 - 1997), as quais foram escritas em diferentes momentos da história que acompanha o primeiro hospício brasileiro, o Pedro II. Para tanto, embaso-me ainda nos estudos de Erving Goffman sobre instituições totais e estratégias de 'mortificação do eu', ou seja, de apagamento da subjetividade que antecede a internação, e nas discussões da indiana Gayatri Chakravorty sobre a possibilidade de o subalterno falar. Objetivou-se refletir que escrever, dentro de estruturas como essa, sobre si mesmo e sobre a condição das(dos) demais internos(as) é um ato insurgente que nasce sob o risco; seja o risco da morte, da loucura, da perda de si mesmo(a) que circunda a própria existência, seja o risco de esquecimento, de reprovação pública e familiar, de silenciamento e de deslegitimação que circunda a sua escrita.
\end{abstract}

Palavras-chave: Loucura; Literatura da Urgência; Lima Barreto; Maura Lopes Cançado; Stela do Patrocínio.

\begin{abstract}
:
In a Foucaultian approach, this study analyzes the relation between word and silence and the urgency of writing, defended by Luciana Hidalgo as singular to the writings of oneself that are born in the confinement, in the narratives Diário do Hospício (1956), by Lima Barreto (1881-1922), Hospício é Deus: diário I (1965), by Maura Lopes Cançado (1929-1993) e Reino dos Bichos e dos animais é o meu nome (2001), by Stela do Patrocínio (1941 - 1997), which were written at different phases of the history that accompanies the first Brazilian hospice, Pedro II. To that end, I am still embarrassed by Erving Goffman's studies about total institutions and strategies of 'mortification of self', that is, the deletion of subjectivity prior to hospitalization, and in the discussions of the Indian Gayatri Chakravorty about the possibility of the subordinate to speak. The objective was to reflect that writing, within such structures, about oneself and about the condition of the other interns is an insurgent act that is born under the risk; whether it be the risk of death, of insanity, of the loss of oneself that surrounds one's existence, whether it is the risk of forgetting, of public and family reproof, of silencing and delegitimation that surrounds his writing.
\end{abstract}

Keywords: Madness. Urgency Literature; Lima Barreto; Maura Lopes Cançado; Stela do Patrocínio.

Escrevo para que / escrever-se possa / algo.

Luciana Sadalla de Avila

1 Entre os muros do hospício Pedro II: quando a literatura é palavra na qual sempre houve silêncio 
O Hospício Pedro II, fundado no ano de 1852, foi o primeiro hospital destinado ao tratamento de alienados mentais no Brasil. Localizado, originalmente, na Praia Vermelha, Rio de Janeiro, em uma chácara afastada do centro da cidade, foi construído a partir de modelos franceses, não só no que concerne à estrutura física, como também em relação ao caráter de fechamento, de expropriação de identidade e do uso de violências físicas e psicológicas como métodos de "cura". Visto de fora, o edifício luxuoso, com suas escadarias de mármore, se assemelhava a um palácio; o que o levou a ficar conhecido como Palácio dos loucos. Lá dentro, entretanto, a alienação era sedimentada em classes sociais.

O desenho arquitetônico, por sua vez, seguia o modelo de panóptico, pensado pelo jurista inglês Jeremy Bentham, no século XVIII, para projetar uma prisão circular na qual os(as) presos(as) seriam vigiados(as) e controlados(as) constantemente por um observador central. Para o filósofo francês Michel Foucault (1975), quem apresenta uma análise consistente sobre a história da loucura e da estrutura manicomial no Ocidente, ele funcionava como um instrumento de poder disciplinador com a finalidade de manutenção da ordem estabelecida pelas estruturas dominantes. Para alcançar esse objetivo de modo mais eficiente, a arquitetura circular, marcada por uma torre central, é complementada por "métodos que permitem o controle minucioso das operações do corpo, que asseguram a sujeição constante de suas forças e lhes impõem uma relação de docilidade-utilidade" (FOUCAULT, 1975, p. 161). Entre essas práticas estão a coação física e moral, a exigência de uniformidade, a imposição de atividade laboral não remunerada.

O uso desses métodos é pensado pelo sociólogo Erving Goffman (2001) como estratégias de 'mortificação do eu' próprias de instituições totais, as quais são entendidas como locais de fechamento que funcionam como estufas com o fim de isolar, homogeneizar condutas, conter e mudar comportamentos advindos de identidades anteriores ao enclausuramento. Como exemplo de instituições que apresentam essas características, cita os presídios, os conventos, os orfanatos, os hospícios. Para ele, o que diferencia uma instituição totalizadora das demais, já que toda instituição tem tendência de fechamento, é o seu caráter de 'fechamento total' "simbolizado pela barreira à relação social com o mundo externo e por proibições a saída que muitas vezes estão incluídas no esquema físico - por exemplo, podas fechadas, paredes altas, arame farpado, fossos, água, florestas ou pântanos" (GOFFMAN, 2001, p. 16).

Devido a essas características, atividades básicas da vida cotidiana que, geralmente, são realizadas em lugares e horários particulares, como dormir, brincar e trabalhar, são rompidas. Todas elas passam a ser praticadas "num mesmo local e sob uma única autoridade". 
Por serem realizadas em conjunto e no mesmo horário, todas as pessoas do grupo, em tese, são "tratadas da mesma forma e obrigadas a fazer as mesmas coisas". Soma-se o fato de que "são reunidas num plano racional único, supostamente planejado para atender aos objetivos oficiais da instituição" (GOFFMAN, 2001, p. 17). Em decorrência disso, observa-se que o ingresso nesses locais, marcado, em sua maioria, pela entrega de documentos e objetos pessoais, deixados na administração, e pela atribuição de um número de identificação, uso de uniformes, corte de cabelo, e/ou proibição de livre contato com a família, constitui o primeiro passo para o apagamento de subjetividade que se seguirá lá dentro.

Considerando, então, que o Hospício Pedro II foi baseado num modelo de vigilância e de fechamento semelhante ao que é apontado por Michel Foucault (1975) e por Erving Goffman (2001), constata-se que a psiquiatria no Brasil nasceu imersa em uma estrutura excludente, controladora, homogeneizadora e punitiva. Diante desse cenário, fica difícil imaginar que qualquer manifestação de subjetividade e de sensibilidade tenha nascido aí e, menos ainda, ultrapassado os muros do edifício. Ainda mais quando se leva em conta que, conforme ressaltado por Foucault (2002, p. 259), "a loucura foi, em todos os tempos, excluída". Uma exclusão que retirou do louco até mesmo a dignidade humana: "aqueles que são excluídos diferem de um domínio ao outro, mas pode acontecer de a mesma pessoa ser excluída de todos os domínios: é o louco" (FOUCAULT, 2002, p. 261). Ao ser atribuído à loucura o caráter de falta, de incapacidade, de desvio, de perigo, de desatino, retira-se qualquer possibilidade de o louco ser considerado um Sujeito. Tratado como anormal, abjeto social, desviante moral, monstro, ele é o "outro", aquele que está "fora de si” e fora das relações sociais (cf. FOUCAULT, 2001).

Soma-se o fato de que as diversas modalidades que mobilizam essa exclusão são perpassadas por outras exclusões que podem ser de âmbito social, político, cultural, sexual, econômico, de gênero. Como é historicizado por Michel Foucault (1995), o hospício surge, entre outros motivos, como uma forma de afastar das cidades o que não é desejado, o que destoa da paisagem social, o que pode transmitir doenças, o que é visto de modo preconceituoso como sujo e perigoso, o que não é produtivo (não realiza trabalho) para o Mercado. Em razão disso, os diagnósticos, em muitos casos, independiam da constatação de existência de delírios ou de instabilidade mental. Consequentemente, diferentes tipos de violência física, psicológica e social, destinadas ao controle da loucura, foram legitimadas e praticadas contra inúmeras minorias sob a proteção dos muros que as mantinham longe da cidade. Algo que se estendeu ao longo do século XX. 
A jornalista Daniela Arbex (2013), por exemplo, constatou em seu estudo sobre o Colônia, localizado em Barbacena, Minas Gerais, que, no final do século passado, "pelo menos 60 mil pessoas morreram" lá. O número alarmante de mortos a leva a considerar o episódio como um verdadeiro "genocídio", algo comparável ao Holocausto. A analogia, segundo ela, surge de um comentário feito em 1979 pelo psiquiatra italiano Franco Basaglia, pioneiro da luta antimanicomial, quando ele compara o Colônia aos campos de concentração: "estive hoje num campo de concentração nazista. Em lugar nenhum presenciei uma tragédia como essa" (ARBEX, 2013, p. 25). Cerca de 70\% dos internos do Colônia não tinham diagnóstico de doença mental". Conforme encontrado nos prontuários médicos, lá eram internados

desafetos, homossexuais, militantes políticos, mães solteiras, alcoolistas, mendigos, negros, pobres, pessoas sem documento e todos os tipos de indesejados, inclusive os chamados insanos. A teoria eugenista, que sustentava a ideia de limpeza social, fortalecia o hospital e justificava seus abusos. Livrar a sociedade da escória, desfazendo-se dela, de preferência em local que a vista não pudesse alcançar (ARBEX, 2013, p. 25-26).

Reitera-se, então, que a loucura não só foi construída culturalmente como ausência total, "a exclusão das exclusões", mas também é interseccionada por outros tipos de supressão. Não bastasse isso, Michel Foucault (1995) analisa que a patologização da doença mental e o consequente surgimento do hospício, no final do século XVIII, cindiram a linguagem de tal modo que a comunicação entre o louco e o "homem de razão" ficou inviável. Isso porque, ao ser delegado à psiquiatria o saber e a voz unilateral acerca da doença mental, perdeu-se a interação com a experiência trágica da loucura e, por conseguinte, com as palavras interditas do louco: "a constituição da loucura como doença mental [...] enterra no esquecimento todas as palavras imperfeitas, sem sintaxe fixa, um tanto balbuciantes, na qual se fazia a troca entre a loucura e a razão (FOUCAULT, 2002, p. 153). Como resultado, o louco perde a possibilidade de representação e/ou autorrepresentação, seja ela no campo político, social, econômico, artístico, e/ou literário.

Contudo, como afirma Michel Foucault (1975), onde há poder há resistência e [...] esta nunca se encontra em posição de exterioridade em relação ao poder" (FOUCAULT, 1988, p. 104-105). Em outras palavras, se existe o domínio da palavra pela psiquiatria, a resistência enquanto contradiscurso também se faz presente. A ausência do ato de resistência significaria que as relações de poder estariam saturadas e, em consequência, viver-se-ia sob a repressão. $\mathrm{O}$ que se comprova pela observação de que, mesmo diante das ausências e silêncios que circundam as estruturas do hospício, existiram relevantes expressões e autoexpressões 
artísticas, políticas e literárias ao longo da história do Pedro II. Entre elas estão três escritas de si que nasceram em diferentes seções e momentos da história iniciada com a fundação desse espaço, a saber; Diário do Hospício (1956), de Lima Barreto (1881-1922), Hospício é Deus: diário I (1965), de Maura Lopes Cançado (1929-1993) e Reino dos Bichos e dos animais é o meu nome (2001), de Stela do Patrocínio (1941 - 1997).

Este estudo se ocupa da análise do comum caráter de resistência/insurgência dessas narrativas literárias, as quais se deram em local de confinamento e, por isso mesmo, de opressão institucional, como forma de lidar com as situações de risco circundantes e como necessidade de dizer (de denúncia). De modo subversivo, aquele e aquelas que foram olhados(as), controlados(as), objetificados(as) pela soberania do poder manicomial, reclamam a própria voz e, através da palavra literária, olham o hospício de volta. Em razão disso, a análise tecida aqui enfatiza as palavras-imagens que constituem os modos como cada "eu" confessado nessas narrativas veem o hospício.

Assim como observado, a opressão característica de instituições totais destitui a subjetividade, a dignidade, a palavra, a identidade dos indivíduos. Escrever, dentro de estruturas como essa, sobre si mesmo e sobre a condição das(dos) demais internos(as), portanto, é um ato insurgente que nasce sob o risco; seja o risco da morte, da loucura, da perda de si mesmo(a) que circunda a própria existência, seja o risco de esquecimento, de reprovação pública e familiar, e de deslegitimação que circunda a sua escrita. Por esse motivo, discuto aqui que essas narrativas trazem em suas poéticas a especificidade da urgência. Essa categoria é defendida pela crítica literária Luciana Hidalgo (2008) como particular, as escritas de si que têm origem em lugares de confinamento.

A escolha do corpus levou em conta o fato de que cada uma dessas narrativas olha pontos específicos das sedimentações sociais presentes desde a fundação do Pedro II. Sobre isso, é necessário salientar que o local inicialmente ocupado por ele é, atualmente, o campus da Praia Vermelha da Universidade Federal do Rio de Janeiro. Devido à superlotação e à decadência da instituição, ao longo das décadas de 1930 e de 1940, os pacientes considerados indigentes foram transferidos para a Colônia Juliano Moreira enquanto os demais foram para o Hospital Engenho de Dentro. A escrita de Lima Barreto se deu na Praia Vermelha. Os pavilhões por onde transitou demonstram sua condição social, racial e, também, os privilégios garantidos pelo status de escritor. Esse privilégio também é denunciado na escrita que Maura Lopes Cançado teceu no Engenho de Dentro, porém com a perspectiva de uma mulher branca, descendente de família nobre. Já Stela do Patrocínio, mulher negra, filha de empregada doméstica e pai desconhecido, expressa a sua dor entre os muros da Colônia Juliano Moreira. 
Nota-se, a partir dessas especificações, que a urgência que atravessa essas narrativas se caracteriza tanto por ter se dado no exato momento em que o "eu" é impelido ao risco como também por ser perpassada por exclusões sociais de raça, de classe social, de gênero. A loucura é, então, pensada junto a silenciamentos que antecedem o diagnóstico de doença mental. Em atenção a esse aspecto, discuto ainda sobre o lugar de fala dos(as) artistas e reflito sobre a possibilidade ou não de o louco ser ouvido, uma vez que ocupa uma posição tão marginal.

\section{A 'escrita da urgência'}

Por que a autoexpressão é tão recorrente em expressões artísticas que nascem no interior de instituições totais, a exemplo do hospício? Para a pesquisadora Luciana Hidalgo, a situação limítrofe determinada pelo isolamento hospitalar constitui o caráter emergencial que desencadeia a necessidade da autoexpressão como modo de assegurar a subjetividade. A esse tipo de escrita, Hidalgo denominou narrativa-limite de si. O que a diferencia dos demais estilos de escrito, segundo afirmado pela pesquisadora em entrevista concedida ao Boletim da Fundação de Amparo à Pesquisa do Estado do Rio de Janeiro (FAPERJ), em 6 de novembro de 2008, é que

[..] a princípio pode-se pensar que grandes escritores da história da literatura escreveram por urgência, no mínimo por angústia, um dos norteadores de boa parte da história das artes. Mas a literatura da urgência vai além nesse preceito ao delimitar o momento exato da escrita como emergência, diferentemente do escritor que escreve no dia-a-dia comum, sem limitações que o impeçam de se libertar de uma situação opressora. Desta forma, a angústia e outras emoções ou ideias que geram a literatura em condições normais de vida pairam como nota de fundo, inspirando um questionamento da existência como um todo. Já a literatura da urgência referese unicamente ao estado que impele o sujeito ao risco, à fronteira limítrofe com a morte, seja por meio da loucura, de uma doença terminal, de uma situação de cárcere ou de outras experiências radicais. (HIDALGO, 2008)

A 'escrita da urgência', portanto, é determinada pelo lugar e o momento exato em que foi desencadeada, os quais condizem com o isolamento em instituições com caráter de fechamento total. Nesses espaços, como já foi mencionado, as normas de funcionamento implicam o apagamento de subjetividades ('mortificação do eu'). Ali dentro, longe de onde a vista ou os ouvidos alcançam, a escrita se dá no limítrofe escrever ou morrer, escrever ou se silenciar, escrever ou ser sucumbido pelas "situações-limites" circundantes. Escreve-se, entre outros motivos, para salvaguardar a identidade constantemente acometida, muitas vezes de modo violento. É dentro dessa perspectiva que Luciana Hidalgo (2006) caracteriza a 'escrita da urgência' como busca por transcendência e por restituição do "eu". Para solidificar essa 
peculiaridade, sua pesquisa tem como base os estudos do filósofo Michel Foucault (2006) sobre a função da escrita de si para o cristianismo e para a filosofia na Antiguidade Clássica.

De acordo com a análise foucaultiana, os clérigos praticavam a escrita de si como um exercício ascético, ou seja, como confissão. Já a filosofia via a prática como exercício etopoiético, cuja finalidade era a de operar uma transformação em ethos, isto é, provocar mudanças na maneira de ser, na conduta ética, ou no modo de existência do indivíduo. A introspecção, então, era vista como ato de reflexão e de transcendência em busca da salvação divina e/ou da moral.

No que se refere à prática da escrita de si como um exercício ascético, ela se constrói como um modo de evitar a concretização do pecado. Colocar os anseios íntimos no papel se aproxima do ato confessional, o que traz para a prática do escrever o papel de um companheiro que enfraquece os perigos da solidão. Diante da possibilidade do constrangimento que a leitura dessas declarações por outrem poderiam causar àquele(a) que escreve, a escrita é uma forma de salvaguardar o "eu" de si mesmo. Assim, semelhante a uma "espécie de pedra de toque", escrever sobre si adquire a função de "revelar os movimentos do pensamento e as sombras interiores [...] onde se tecem as tramas do inimigo" (FOUCAULT, 2006, p. 144). Enfim, numa perspectiva cristã, escrever sobre si é cuidar de si por meio da renúncia dos desejos íntimos com o intuito de alcançar a salvação eterna.

Quando se pensa na escrita de si que se dá em meio à urgência, sobre a qual Luciana Hidalgo (2008) discute, o entrecruzamento entre o ambiente totalitário, os mecanismos de controle social, a subjetividade subalternizada, a angústia e a melancolia diante da vida, propiciam o olhar para a escrita autobiográfica como necessidade de afirmação de si, como $\begin{array}{llll}\text { companheira } & \text { para limítrofes }\end{array}$ (morte/loucura/doença/encarceramento) e, até mesmo, resistência frente à produção de identidades dóceis em ambientes totalitários. Isso porque a arte da urgência "pode funcionar como uma reconstituição de si, promovendo a reunião dos fragmentos de um capital de primeira necessidade: $e u$ " (HIDALGO, 2006, p. 13). Desse modo, organizar de forma narrativa a própria vida no papel é também conferir totalidade à existência.

Uma outra característica da 'escrita da urgência' observada por Luciana Hidalgo (2008) corresponde a constatação de que ela, geralmente, é distendida em ficção de si, após o término do confinamento. A autoficcção que resulta desse processo é denominada por Hidalgo (2008) como literatura da urgência. Por esse viés, a pesquisadora entende que o Diário do hospício (1956), escrito por Lima Barreto durante a internação, equivale à 'escrita da urgência', o que pode ser constatado pela precariedade material em que se deu a escrita: 
anotações diárias, à lápis, em papéis fornecidos por um psiquiatra. Também há alguns trechos rasurados e outros não terminados. Assim sendo, a 'escrita da urgência' é uma escrita sem filtro. Em contrapartida, a narrativa Cemitério dos vivos (1956), escrita que ficcionaliza as notas do diário e, por conseguinte, a memória da urgência em que elas se deram, constitui-se enquanto literatura de si. Há aí um cuidado maior com a escrita, com o refinamento textual e com os aspectos formais e estéticos.

\section{Pode o louco falar?}

A urgência da escrita, quando pensada de modo a se considerar os silêncios e ausências que constituem a história da loucura, é atravessada pela falta de legitimidade estabelecida culturalmente em torno da palavra do louco. Por essa razão, os extremos com o qual essa escrita lida perpassam ainda o risco das palavras serem abafadas pelos muros manicomiais. Isso não significa que a escrita em outras instituições totais, tal como um orfanato ou um convento, estejam livres desses silenciamentos. $\mathrm{O}$ recorte se faz necessário devido ao fato de que a linguagem do louco foi deslocada do campo linguístico. O louco, conforme foi construído em nossa cultura, não só perdeu a possibilidade de autorrepresentação como também a forma de linguagem com a qual poderia se comunicar. Diante do saber, da razão, a palavra do louco é a linguagem sem sentido, sem nexo, inconsciente. Ela é silêncio no que concerne à posição de subalternidade e, também, ao distanciamento da linguagem racional.

Sobre esses aspectos, Michel Foucault (2002) afirma que a loucura é uma obra ausente, a falta de linguagem, a fábula não contada. Por fábula, o filósofo entende tudo aquilo que pode e deve ser dito. Daí ele observar a importância da aproximação entre loucura e literatura, que se deu ao longo do século XIX, para que essa linguagem fosse reinserida em nossa cultura. Segundo ele, escritas transgressivas que se fizeram no interior de instituições com caráter de fechamento no final do século XVIII e início do século XIX, a exemplo da escrita de Antonin Artaud (1896-1948), são significativas por incluir na literatura a fala dos excluídos e, consequentemente, evidenciarem "a relação de uma cultura com aquilo mesmo que ela excluiu" (FOUCAULT, 2002, p. 211). A literatura produzida por loucos, nesse sentido, transgride a incompatibilidade entre literatura e loucura construída por nossa História:

ao entrar em um outro domínio da linguagem excluída (naquele fechado, sagrado, temido, erigido na vertical acima dele próprio, reportando-se a si em uma prega inútil e transgressiva, 
que chamamos de literatura), a loucura desenlaça seu parentesco, antigo ou recente segundo a escala que se escolha, com a doença mental (FOUCAULT, 2002, p. 2019).

A literatura que resulta desse encontro nasce transgressiva e subversiva. A fábula que se constrói a partir dele se fez enquanto murmúrio. Ciente, entretanto, de que a literatura é um espaço político e discursivo entremeado por relações sociais e construções históricas e sociais que podem ser problematizadas e/ou reafirmadas pela perspectiva e escolha de quem escreve, há de se ter em mente que o imaginário em torno da fala do louco ainda incide sobre o direito de representação. Resta, então, nos questionar, como é proposto pela crítica e teórica indiana Gayatri Chakravorty Spivak (2010), se essas vozes, ao adentrarem um espaço historicamente construído como não pertencente a elas, podem ser ouvidas. Ainda mais quando se sabe que a loucura é perpassada por diferentes categorias de exclusão e que, como afirma a crítica literária Regina Dalcastagnè (2012, p. 7), o que “está em jogo é a possibilidade de dizer sobre si e sobre o mundo, de se fazer visível dentro dele".

Em face dessas ponderações, o anseio por se fazer visível, por assegurar e afirmar a subjetividade em espaços totalitários envolve a reflexão sobre outras identidades subalternas, tais como identidades de gênero, identidades sexuais, identidades raciais e identidades econômicas. O modo como é afetado pelas relações sociais constitui situações que limitam o indivíduo entre o silêncio e a resistência aos mecanismos de poder. Assim, os vestígios da exclusão social na escrita também representam a urgência na qual ela se deu. Não por acaso, o racismo sofrido por Lima Barreto, a título de exemplificação, é recorrente em seu relato e caracteriza o modo como olha para o hospício e, consequentemente, denuncia como ele, e os de sua cor e raça, são olhados pelas instituições manicomial e policial. Sem contar que, quando esses sujeitos trazem junto a necessidade da escrita o anseio por ser reconhecido publicamente como escritor(a), a escrita pode ainda ser atravessada pela urgência financeira e pela emergência de falar com legitimidade.

É importante ressaltar que a subalternidade é uma categoria historicamente construída e fortalecida pelo discurso hegemônico. Basicamente, como é afirmado por Gayatri Chakravorty Spivak (2010), ela é constituída por modos específicos de exclusão, o que implica em limitação da representação política e legal. Consequentemente, retira-se a possibilidade de o subalterno se tornar membro pleno no estrato social dominante. Dessa maneira, se há um discurso preponderante que cerceia a participação ativa e a representação do outro, seja ela política e/ou performática, a voz do oprimido, sem qualquer forma de agenciamento, é impossível de ser ouvida. Frente a essa impossibilidade e apoiada a um posicionamento pós-colonial, a crítica indiana afirma que é papel do intelectual organizar 
espaços de interação onde a transação entre a voz do subalterno e a do ouvinte possa ser efetivada.

Para a construção desses espaços dialógicos de interação é preciso ponderar que existe uma violência epistêmica orquestrada para constituir o sujeito colonial como "outro", o que torna complicado organizar atos de resistência sem que eles estejam sobrepostos ao discurso hegemônico, ou seja, o intelectual deve oferecer modos de trabalhar contra a subalternidade e, consequentemente, problematizar a própria perspectiva eurocêntrica do saber e do conhecimento. Nas palavras de Spivak (2010):

para o 'verdadeiro' grupo subalterno, cuja identidade é a sua diferença, pode-se dizer que não há nenhum sujeito subalterno irrepresentável que possa saber e falar por si mesmo. A solução do intelectual não é a de se abster da representação. O problema é que o itinerário do sujeito não foi traçado de maneira a oferecer um objeto de sedução ao intelectual representante (SPIVAK, 2010, p. 63).

Assim, a constituição marginalizada e inferiorizada do "outro" por um discurso eurocêntrico se apoia ainda em práticas que visam propiciar o desinteresse do intelectual em visibilizar as estratégias de poder que consolidam as subalternidades. O outro como sujeito é inacessível quando se tenta falar por ele a partir de um ponto de vista europeu. Por outro lado, os que buscam confrontar as próprias crenças como leitores e produtores de conhecimento se veem constantemente questionados e deslegitimados pelo saber dominante. Desse modo, questionar os saberes hegemônicos é também se colocar na linha de fogo e, certamente, ser reduzido a "nichos", recorte inferior de uma ciência e/ou arte maior, sendo frequentemente questionado(a) quanto a legitimidade e a natureza das ideias que defende. Por isso o papel do(a) intelectual defendido por Spivak implicar atos de rebeldia, resistência e insurgência.

Não muito distante dessas reflexões, o filósofo e escritor Jean-Paul Sartre (2015), quem vai na contramão da literatura que basta por si mesma, defendida por Foucault (2002), por propor uma literatura engajada politicamente, vê o(a) escritor(a) como um intelectual que pode oferecer espaços dialógicos de interação onde a voz do subalterno possa ser ouvida ou mesmo o direito a representação do outro possa ser problematizado. Para ele, a literatura é ato e, por isso mesmo, não é alheia ao mundo, não é um fim em si mesma. Na verdade, se constitui a partir da perspectiva de quem escreve, do contexto histórico, cultural, social e político representado e para quem é destinada. Desse modo, a prática literária também é movimento:

o ato criador é apenas um momento incompleto e abstrato da produção de uma obra; se o escritor existisse sozinho, poderia escrever quanto quisesse, e a obra enquanto objeto jamais viria à luz: só lhe restaria abandonar a pena ou cair no desespero. A operação de escrever 
implica a de ler, como seu correlativo dialético, e esses dois atos conexos necessitam de dois agentes distintos. É o esforço conjugado do autor que fará surgir esse objeto concreto e imaginário que é a obra do espírito. Só existe arte por e para outrem (SARTRE, 2015, p.41)

Dentro desse movimento, a ação do(a) escritor(a) é perpassada pelas exigências e intervenções do público. Para Sartre (2015), os laços de dependências sociais e econômicas com a classe dominante determinam o foco das narrativas. Por isso, a perspectiva representada pela literatura apresentar traços tão homogêneos em sua historiografia. Afinal, na Idade Média, quando o direito da escrita e da leitura eram privilégios da Igreja, os clérigos escreviam para os clérigos sobre temas que só eles conheciam. Da mesma forma, no século XVIII, após a ascensão da burguesia, os burgueses escreviam apenas para os burgueses com vista a apresentar uma ideia universal do mundo. A pretensão à universalidade era também um posicionamento político adotado pela burguesia, uma vez que anula a existência da diferença e da opressão. Apenas a partir do século XX, após duas guerras mundiais e o advento das lutas sociais por igualdade de direitos, percebeu-se na literatura uma abertura para propagação de vozes e pontos de vistas dissonantes do poder dominante. Algo que para Sartre (2015), e que corroboro aqui, em muito foi fortalecido pelo avanço da democracia: sem ela não há liberdade para escrever, nem para ler.

É bem verdade que o conceito de literatura defendido por Sartre (2015) é utópico, e que a literatura plena sugerida por ele só poderia existir em uma sociedade ideal, onde a liberdade para escrever seria garantida, já que não teria um poder dominante que mantivesse o controle sobre ela e, então, a escrita e a leitura seriam um direito de todos. Entretanto, interessa-me a importância dada à democratização e à observação de que, mediante a existência de discursos hegemônicos, vozes divergentes sempre encontrarão obstáculos, mas que isso não significa que alguns não possam ouvi-las. Afinal, conforme é afirmado por ele ao refletir sobre a literatura do escritor negro Richard Wright, "um iletrado sempre pode aprender a ler; Black boy pode cair nas mãos do mais dos obstinados dos negrófobos e abrirlhe os olhos. Isso significa apenas que todo projeto humano ultrapassa seus limites de fato...” (SARTRE, 2015, p. 69).

Posto isso, sendo a literatura um campo de disputas políticas, o lugar de fala também deve ser considerado quando se pensa a emergência em que se deu a escrita. Isso por considerar, entre outros aspectos, que a urgência do indivíduo historicamente silenciado por relações de poder que perpassam a sua existência o impulsiona a uma escrita que se constrói enquanto autoafirmação. Além disso, ao se ter em mente que dentro das relações de poder, o outro (o subalterno) é construído enquanto grupo, observa-se que a busca por autoafirmação 
se estende do âmbito individual para o coletivo. Vejamos, então, como essas ausências e silenciamentos são vistos por Lima Barreto, Maura Lopes Cançado e Stela do Patrocínio.

\section{Hospício: um cemitério de vivos}

Numa noite de Natal, em 1920, após uma denúncia feita por familiares, um homem negro, na casa dos 31 anos, foi almejado pela polícia, colocado numa "antipática almanjarra de ferro e grades" e, em seguida, conduzido para o Hospício Pedro II, no Rio de Janeiro. O motivo: delírios causados pelo alcoolismo. Lá dentro, em notas de papel doadas por um psiquiatra, escreveu: "estou no Hospício ou, melhor, em várias dependências dele, desde o dia 25 do mês passado. Estive no pavilhão de observações, que é a pior etapa de quem, como eu, entra para aqui pelas mãos da polícia”.

O "eu" confessado nessas linhas é do jornalista e escritor Afonso Henriques de Lima Barreto. O status que antecede o seu nome, é bom ressaltar, não o livrou das exclusões sociais destinadas pelo poder dominante aos de sua classe social e cor. Porém, em muito contribuiu para o acesso a oportunidades dificilmente desfrutadas por outros(as) internos(as), tal como o acesso à biblioteca.

A materialidade da escrita dentro desse ambiente, no entanto, evidencia a precariedade na qual ela foi produzida: anotações feitas à tinta e a lápis em tiras de papel e folhas almaço concedidas por um psiquiatra que o conhecera antes da internação. Nelas é possível observar a intenção do escritor de distender a escrita em um romance. A possibilidade dessa produção foi, inclusive, anunciada em entrevista ao jornal A Folha, em 31 de janeiro 1920.

\footnotetext{
Nessas páginas contarei com fartura de pormenores as cenas mais jocosas e as mais dolorosas que se passam dentro dessas paredes inexpugnáveis. Tenho visto coisas interessantíssimas. Agora só falta escrever, meter em forma as observações reunidas. Esse trabalho pretendo encerrar logo que saia daqui, porque aqui não tenho as comodidades que são de desejar para a feitura de uma obra dessa natureza (BARRETO, 1920).
}

Apesar do anúncio, a obra, a qual deu o nome de Cemitério dos vivos, ainda não estava acabada quando, dois anos depois, em 1922, veio a falecer. Em vida, presenciou apenas a publicação do primeiro capítulo, a qual foi feita pela revista Souza Cruz, em janeiro de 1921. Em 1949 deram entrada desses manuscritos na Biblioteca Nacional, mas apenas em 1956 foram organizados pelo biógrafo Francisco Assis Barbosa e publicados pela Editora Brasiliense. O que leva à observação de que ainda que o escritor tenha feito denúncias e reflexões acerca da loucura e do ser louco/alcóolatra a partir do olhar de um homem negro marginalizado socialmente, a sua voz não ecoou em sua época. 
Além disso, o fato de não ter conseguido publicar os textos em muito evidencia a instabilidade financeira em que se encontrava. Afinal, como muitas vezes denunciou, a crítica literária era bastante fechada aos estilos que se distanciavam do modelo considerado literatura maior, o que fazia com que a publicação de textos insurgentes, como os seus, fossem possíveis apenas por meio de apadrinhamentos. Essa situação fez com que pagasse do próprio bolso a tiragem de Triste fim de Policarpo Quaresma (1915), a título de exemplificação. Fora isso, o conteúdo e a temática desenvolvida, como é possível imaginar, não devia ser de interesse do campo literário da época. Mesmo com as discussões propostas pelo escritor acerca da necessidade de se criar um público leitor diversificado, a verdade é que ele ainda era muito restrito e homogêneo. Não por acaso, parte de suas obras e críticas só foram publicadas após a sua morte. Muitas delas, inclusive, haviam sido escritas após a internação, a exemplo de Clara dos Anjos (1948).

Apesar dos obstáculos que dificultaram o texto barretiano de dialogar com o público virtual $^{1}$, para quem foi originalmente destinado, a publicação póstuma ofereceu a oportunidade das críticas e denúncias apresentadas ressoarem em um momento no qual as estratégias e práticas do sistema psiquiátrico estavam sendo questionadas. Salienta-se ainda que a publicação se deu em um cenário histórico no qual a arte produzida por loucos(as) estava sendo bastante discutida nos grandes centros culturais do país. O que, em grande parte, foi disseminado pelo projeto inovador da psiquiatra Nise da Silveira ${ }^{2}$, que buscou humanizar os tratamentos terapêuticos por meio do incentivo à criação artística.

A condição social e as exclusões raciais vivenciadas pelo autor ao longo de sua vida estão entrelaçadas à representação que faz do louco, do hospício e do modo como a Primeira República, aliada ao poder policial e ao poder manicomial, fazia uso do aparelho do Estado para vigiar, excluir, punir os desviantes. Considerados "vagabundos", indigentes,

\footnotetext{
${ }^{1}$ O termo, aqui, é uma referência a Jean-Paul Sartre (2015 [1948]), em Que é a literatura?, quando diferencia o público real de um escritor, aqueles que efetivamente lerão a obra, dos que são construídos como destinatários no momento da escrita, o público virtual.

${ }^{2}$ É necessário pontuar que a psiquiatra Nise da Silveira foi uma das pessoas atingidas pelas perseguições políticas durante a ditadura Vargas. Foi presa pela primeira vez em 20 de fevereiro de 1936, por ter pertencido à união Feminina Brasileira, entidade feminista brasileira fechada pelo governo dois meses depois de criada. Foi posta em liberdade no mesmo dia. Mas em 26 de março do mesmo ano, foi presa novamente e, em seguida, transferida para o presídio da Rua Frei Caneca, onde permaneceu até 21 de junho de 1937. Devido a novas ondas de prisões, cinco meses depois de sua liberdade, se refugiou na Bahia e em outros estados do Nordeste e do Norte. De forma que o projeto que resultou na construção da Seção Terapêutica Ocupacional, no Centro Psiquiátrico Nacional, em Engenho de dentro (Depois Centro Psiquiátrico Pedro II, e, atualmente, Instituto municipal Nise da Silveira) só foi possível porque uma onda de democratização do país no final da Segunda Guerra Mundial lhe permitiu ser readmitida no serviço público. O que não quer dizer que as inovações apresentadas para uma terapêutica mais humanizada foram aceitas sem percalços.
} 
degenerados, restava-lhes a segregação por meio do encarceramento nas penitenciárias e/ou no hospício. Nesses casos, quem decidia se o indivíduo era louco ou não era a polícia.

Não me incomodo muito com o hospício, mas o que me aborrece é essa intromissão da polícia na minha vida. De mim para mim, tenho certeza que não sou louco, mas devido ao álcool, misturado com toda a espécie de apreensões que as dificuldades de minha vida material há 6 anos me assoberbam, de quando em quando dou sinais de loucura: deliro. (BARRETO, 2009, p.3)

O que mais o incomoda a respeito da arbitrariedade do poder policial é que ela é fortalecida pelo elo com uma ciência que encontra em toda e qualquer demonstração de desvio de conduta moral um tipo de loucura: "pavilhão de observação é uma espécie de dependência do hospício a que vão ter os doentes enviados pela polícia, isto é, os tidos e havidos por miseráveis e indigentes, antes de serem definitivamente internados" (BARRETO, 2009, p. 60). Com o aval do Estado, fazia uso constante de métodos e medicamentos recém estudados e criados na Europa, sem ponderar os efeitos e consequências desses procedimentos.

Assim, a reclusão é o reflexo da ação totalizadora do aparelho policial e de uma psiquiatria ainda presa a métodos medievais de controle e tortura. A internação no hospício não tem o objetivo de curar a insanidade ou amenizar o sofrimento dos indivíduos, antes lugar de isolamento e punição.

\footnotetext{
é uma triste contingência, esta, de estar um homem obrigado a viver com semelhante gente. Quando me vem semelhante reflexão, eu não posso deixar de censurar a simplicidade dos meus parentes, que me atiraram aqui, e a ilegalidade da polícia que os ajudou. Caído aqui, todos os médicos temem pôr logo o doente na rua. A sua ciência é muito curta, muito prevê; mas seguro morreu de velho e é melhor empregar o processo da Idade Média: a reclusão. (BARRETO, 2009, p. 20)
}

A perspectiva marginal do escritor negro, nesse sentido, visibiliza as amarras do sistema opressor. A questão não é apenas assinalar que existem pessoas não insanas junto àquelas acometidas pela loucura, antes denunciar que esses que aí estão inseridos têm cor e classe social bem definida. O hospício é exposto como uma extensão das segregações sociais que foram base do projeto de colonização do país: um sistema de produção escravagista baseado na exclusão e na exploração daqueles considerados inferiores. Aos que se insurgem contra a norma estabelecida são desenvolvidas estratégias de correção. Antes o tronco e/ou a morte. Com a abolição da escravatura, são asseguradas por espaços de segregação: "a polícia, não sei como e porquê, adquiriu a mania das generalizações, e as mais infantis. [...]Todo o 
cidadão de cor há de ser por força um malandro; e todos os loucos hão de ser por força furiosos e só transportáveis em carros blindados" (BARRETO, 2009, p. 61).

Ao descortinar o isolamento característico do poder manicomial, Lima Barreto se atenta ao fato de que, embora não privilegie o tratamento e a cura, os hospícios possuem estratégias de homogeneização dos sujeitos: os uniformes, a nudez coletiva, os horários determinados para práticas coletivas. Em decorrência disso, nota-se em sua escrita a contínua marcação da diferença em relação aos demais: ele lê jornais, escreve, lê diferentes literaturas na biblioteca. Assim, a prática da leitura e da escrita são construídas como modo de lidar com a uniformização característica do poder manicomial, assegurando a subjetividade.

A autoafirmação é tão peculiar à escrita barretiana que no projeto de ficcionalização das notas diárias, ele constrói uma autorrepresentação envolta em memórias e em narrativas imaginadas, que muito parece buscar uma aproximação com a vida do pai e da mãe, para particularizar a vida do indivíduo: marcar a existência de uma história singular antes da isolação hospitalar.

Desse modo, a perspectiva de Lima Barreto em relação à loucura e a representação de si evidencia a insatisfação diante das injustiças sociais e da imposição do saber legitimado como aparelho de reclusão. A visibilidade e as denúncias presentes são construídas por um caráter insurgente, o que caracteriza uma 'escrita da urgência' atravessada por opressões raciais e silenciamentos. Hospício é um cemitério de vivos: um lugar reservado aos indigentes. Segregados pelos muros físicos e imaginários, resta-lhes esperar a morte e a certeza de que não podem ir além.

\section{Hospício: um deus vigilante e opressor}

Três anos após a primeira publicação de Cemitérios dos vivos (1956), a escritora mineira Maura Lopes Cançado, na época com 30 anos, escrevia, em uma ala do então chamado Centro Psiquiátrico Nacional, Engenho de Dentro, o diário que seis anos mais tarde seria publicado com o nome Hospício é Deus: diário I. Não há evidências de que a obra barretiana tenha sido lida pela escritora mineira ou que pode ter influenciado e motivado a sua escrita. Contudo, a possibilidade não pode ser descartada, já que ela era uma leitora assídua.

É necessário salientar de antemão que, diferente de Lima Barreto, Maura Cançado era branca e descendente de nobres e ricos fazendeiros. Fazia parte da tradicional família mineira da pequena cidade de São Gonçalo do Abaeté. O privilégio social certamente foi importante para que sua produção literária se tornasse pública, principalmente quando se pensa, por exemplo, a maior probabilidade de conhecer pessoas influentes nos ambientes em que 
frequentava e, também, as oportunidades educacionais e o acesso mais facilitado a diferentes leituras.

Por outro lado, ao se levar em consideração que dentro das relações de poder "o sujeito é dividido no seu interior e em relação aos outros" (FOUCAULT, 1995, p. 232), os privilégios de cor e classe social não impediram que fosse atingida por práticas de opressão de gênero características de uma sociedade conservadora (como se sabe, o machismo afeta, de diferentes modos, a todas nós mulheres): foi violentada sexualmente aos cinco ou seis anos; sofreu a imposição da imagem de um deus onipresente que condenava o sexo e os desejos íntimos; se viu vigiada e controlada pelos olhares questionadores de uma sociedade conservadora, quando optou por ser aviadora; foi vítima da exclusão social que a impediu de estudar, ou de compartilhar espaço com as moças e mulheres casadas que compunham as “famílias de bem”, por ter sido mãe aos quinze anos e ter se separado logo em seguida; sofreu, angustiada, o avançar de homens casados munidos da alegação de que, por ser separada, não poderia dizer não.

De forma análoga, enquanto a escrita de Lima Barreto visibiliza os privilégios alcançados pelo status de escritor e a memória do racismo sofrido pelo autor ao longo da vida, a perspectiva adotada por Maura Lopes Cançado para narrar a loucura e o cotidiano no hospício é perpassada pelos privilégios usufruídos e pelas opressões de gênero sofridas. Dentro dessa construção, ela denuncia as estratégias de vigilância e de controle que a fizeram candidata aos hospícios onde foi parar.

\footnotetext{
Diziam-me à moça mais bonita e prendada da cidade. Lamentavam que me tivesse já casado. Aquilo me irritava deveras. Lera muito sobre os costumes de outras terras, julgava-me na situação de uma divorciada (ou menos comprometida). Por que privar-me das diversões comuns às moças da minha idade? Mas as pessoas pensavam diferente. Atravessei nesta época uma fase completamente niilista. Li todos os filósofos que me caíram às mãos. Não possuindo ainda grande defesa, deixei-me impregnar de negativismo apenas. Pensei pela primeira vez em me matar. (CANÇADO, 1991, p. 24).
}

Nota-se, então, que o "eu-confessor" de Cançado se dirige à burguesia conservadora de modo a apontar as suas incoerências e as suas hipocrisias. A escrita diária põe na vitrine literária as imposições sociais e a forma como elas a conduziram ao estado de depressão, desajustamento social e desequilíbrio mental em que se encontra no presente da narrativa. Esse intuito fica evidente pela forma como essa relação causa e consequência é marcada na estrutura de Hospício é Deus. Em um primeiro momento, são apresentados fragmentos das memórias da infância e da juventude e como as convenções sociais foram limitando os seus desejos, a sua subjetividade, a sua liberdade. A imposição de um deus vingativo a vigiar seus 
comportamentos e desejos a assustava de tal modo que passou a vê-lo como o demônio de sua infância. Em um segundo momento, essas imagens são ressignificadas e entrelaçadas ao relato do cotidiano no hospício traçado pela escrita datada. A fronteira que divide uma parte da outra, por sua vez, é marcada pela responsabilização da imposição burguesa. Fazendo uso de uma linguagem de caráter acusatório e desafiador, ela afirma que sofreu

com brutalidade os reflexos do condicionamento imposto a uma adolescente numa sociedade burguesa, principalmente mineira - e principalmente quando esta adolescente julga perceber além das verdades que lhe impõem e, tem, ela mesma, sua própria verdade, É, portanto, a metade do meu álbum: apresentei a moça de dezesseis anos, bonita, rica, aviadora; sem futuro - mas uma grande promessa. (CANÇADO, 1991, p. 26).

Por essa marcação, o "eu-confessor" visibiliza as relações entre o poder manicomial e o poder patriarcal. Sobre essa ligação, a feminista estadunidense Elaine Showalter (1985), ao estudar a relação entre mulher e loucura na cultura patriarcal inglesa entre anos de 1830 a 1980, relata que estatísticas documentadas por historiadores e psiquiatras apontavam que mulheres eram maioria entre as(os) pacientes internadas(os) em hospitais psiquiátricos públicos no século XIX. No século XX, uma estatística semelhante também foi percebida em hospitais particulares. Concluiu-se, então, que a loucura seria uma doença feminina.

Ao problematizar os motivos que possam justificar essa proximidade estatística entre mulher e loucura, Showalter $(1985$, p. 3,4$)$ destaca a condição social das mulheres diante dos papéis de gênero produzidos pelo discurso patriarcal que sustentava as práticas manicomiais. Acrescenta ainda que a psiquiatria inglesa do século XIX encara a desordem mental entre homens e mulheres de modo diferenciado. Sintomas semelhantes são observados em homens como consequência de um desenvolvimento civilizacional (progresso) que passa a exercer pressões sociais e econômicas, e, em mulheres, como próprios de uma doença feminina associada à sexualidade e à natureza essencial da mulher. As práticas psiquiátricas, dessa forma, confirmam e fortalecem mecanismos do poder patriarcal.

No que diz respeito à publicação do diário, é importante ressaltar que, diferente de Lima Barreto, sua escrita foi apadrinhada ou, como afirma no diário, foi intermediada por seus "protetores", Reynaldo Jardim, Ferreira Gullar, Assis Brasil, e tantos outros "bons intelectuais da nova geração" (CANÇADO, 1991, p. 28). Reynaldo Jardim, por exemplo, foi quem lhe sugeriu que escrevesse o diário. Ele também fazia parte, junto com os demais, da coordenação do Suplemento Dominical do Jornal do Brasil (1956-1961), no qual a escritora ficou conhecida por colaborar com a publicação dos contos que mais tarde foram reunidos e publicados com o título $O$ sofredor do ver (1968). 
A dependência de pessoas influentes economicamente e inseridas nos movimentos literários vigentes, todavia, também foi criticada pela escritora mineira. Sobretudo quando percebeu "um certo empenho da parte de várias pessoas" em impedir a publicação de seus textos. Apesar da boa crítica recebida inicialmente, o posicionamento ético em relação ao uso de nomes de personalidades e suas vivências no relato diário foi bastante questionado. $\mathrm{O}$ segundo diário, por sua vez, nem ao menos foi publicado. Críticas divulgadas no Jornal do Brasil afirmam que o manuscrito foi lido por algumas pessoas. Alguns(as) daqueles(as) que viram seus nomes e ações citadas reivindicaram o direito de fazer cortes ou impedir a publicação. Durante um bom tempo, o manuscrito perambulou nas mãos de editores que, por um motivo ou outro, não o publicaram. Até que um dia, por coincidência, ou não, o original foi "esquecido" por um editor dentro de um táxi.

Quanto às críticas presentes na primeira parte do diário, ressalta-se ainda que não foram bem recebidas por parte considerável da burguesia da época. Em entrevista à revista Leitura, em dezembro de 1968, Cançado relata que recebeu cartas que, em determinados pontos, ponderavam que ela

deveria ser considerada à distância, por constituir ameaça à civilização ocidental e cristã (Isto quando não o usaram para ameaçar-me: recebi uma gentilíssima carta de uma repórter, onde ela ameaçava bater-me até deixar-me quase morta, em seguida internar-me num "Hospício Sem Deus", de onde eu não poderia mais sair) (CANÇADO, 1968).

Como é possível observar a partir desse relato, a recepção agressiva mostra que a mensagem da escrita atingiu o público ao qual foi destinado. $\mathrm{O}$ incômodo diante das denúncias de hipocrisia e da visibilidade das amarras que sustentam o poder patriarcal é claro. Todavia, a leitura não propiciou em muitas dessas pessoas a autorreflexão esperada. Em consequência disso, como era possível prever, a referencialidade de sua produção passou a ser questionada diante do status de insanidade. A autoexpressividade recorrente em sua escrita passou a ser vista pela crítica como falta de amadurecimento literário, os editores passaram a recusar seus textos.

A exclusão e silenciamento a qual submeteram a sua escrita chega a ser questionada na entrevista à revista Leitura, mencionada anteriormente. As justificativas da singularidade e da originalidade de sua poética são colocadas junto ao apelo aos agentes literários para que reconheçam a qualidade de suas obras e viabilizem a publicação. $\mathrm{O}$ tom apelativo, entretanto, é amarrado por nuances críticas, sarcásticas, irônicas e acusadoras. Sem abaixar a cabeça, ela fala da dificuldade imposta pelo cânone literário para criações literárias que fogem à norma e expõe a prática comum de uma crítica construída por relações de amizades: "Vislumbra-se a 
'grande eficiência das imorredouras amizades': o crítico-escritor amigo do escritor. O escritor amigo do escritor-crítico. Está feita a crítica". Por fim, denuncia as superficialidades e as relações de aparências envolvidas nesse processo:

[...] faço empenho em acrescentar: não sou feia como mostram meus retratos. Antes, muito bonita. E bem mais jovem. Nasci em 1931. Não sou fotogênica é a verdade. E ainda: Por que não lançam meu livro? E não me dão uma coluna num importante jornal? Por que não reconhecem que sou a maior escritora brasileira? Ou não me sustentam principescamente para que eu possa produzir e pensar (CANÇADO, 1968, p. 21).

Ao longo de sua vida no Rio de Janeiro, trabalhou em diferentes lugares e desempenhou diferentes funções, foi inclusive funcionária pública, porém sua dedicação maior consistia em realizar o sonho de se tornar "a melhor escritora do Brasil". Diante dos obstáculos à consolidação desse desejo e do agravamento da precariedade econômica e psicológica, aos poucos foi abandonando a escrita. Até mesmo o amor e a admiração pelas obras publicadas. Essas circunstâncias se tornaram ainda mais complicadas quando assassinou uma jovem interna, durante uma das internações na Clínica de Saúde Dr. Eiras, em 1971.

Como o episódio aconteceu em um momento que o Brasil não dispunha de hospitais de custódia apropriados para mulheres, perambulou por diferentes clínicas psiquiátricas e penitenciárias, sofreu descasos, violências e diferentes tipos de silenciamentos: o desaparecimento de livros que estava escrevendo, a negação do direito ao uso de instrumentos necessários à escrita, a perda parcial da visão. Em decorrência disso e demais angústias, mesmo após a liberdade vigiada, consentida em 1980, não escreveu mais. Foi esquecida pela crítica até ser resgatada pelos Estudos Culturais literários e pelos estudos feministas a partir dos anos de 1990, movimentados principalmente pela notícia de sua morte, em 1993.

No que concerne às marcas da urgência presentes em sua escrita, salienta-se que ela também se deu de modo precário, em situações de pouca luz e de incômodo gerado pela interferência de outras internas. Antes de ser presenteada com um bureau que lhe foi dado por Dr. A, psiquiatra responsável por sua ala e por quem se apaixonou, escrevia sobre a cama ou sobre as penas, com toco de lápis, em folhas também cedidas pelo psiquiatra. Junto as suas anotações, às vezes encontrava rabiscos, desenhos e/ou reflexões feitas por Durvaldina, uma interna que sofria de esquizofrenia.

Salienta-se, entretanto, que, diferente de Lima Barreto, ela não foi conduzida ao hospício, de modo direto, por nenhum poder institucional. Devido à instabilidade emocional e econômica pela qual passava, pediu para ser internada buscando ajuda terapêutica e abrigo. $\mathrm{Na}$ situação-limite em que se encontrava, pouco sobrava da jovem descendente de uma das 
famílias mais abastadas de São Gonçalo do Abaeté. A menina que cresceu em meio às proibições e sanções de uma sociedade de estrutura patriarcal não soube lidar com as desestabilizações emocionais, o isolamento, os rótulos, as pressões, as angústias, e todas essas estratégias utilizadas pelo patriarcado para silenciar os que se insurgem contra as regras estabelecidas. O dinheiro herdado após a morte do pai foi gasto deliberadamente na busca por aceitação e afeto. O consumo cada vez maior de álcool e as constantes noites boêmias agravaram ainda mais o seu estado. No momento da escrita, ela se encontrava distante geográfica e afetivamente da família, sem dinheiro e nem moradia. Não dispunha nem mesmo de uma máquina para escrever.

Além desse aspecto, um outro ponto que distancia a urgência em Cançado da vivenciada pela escrita de Lima Barreto é que as notas diárias da escritora passaram por edição. Consequentemente, o que chegou ao público sofreu alguns acréscimos e exclusões, ou seja, houve um cuidado maior com os aspectos formais e estéticos do texto. A 'escrita da urgência' em Cançado foi a público já como 'literatura da urgência'. A ficção de si mesma, da loucura, e das pessoas com quem conviveu durante o confinamento é construída nos contos que constituem a coletânea $O$ sofredor do ver. Esses contos, no entanto, não foram todos escritos após o término da internação em que se deu a escrita do diário. Pelo contrário, alguns foram escritos durante esse e outros confinamentos. Assim sendo, a urgência e a ficcionalização da dor vivida são traços determinantes na poética da escritora.

\section{Hospício é hospício: estar internada é ficar todo dia presa}

Um ano antes da morte de Maura Cançado, em uma das ramificações do Hospital Pedro II, morreu, desconhecida e em silêncio, já que devido a uma infecção generalizada, iniciada por uma hiperglicemia grave, havia parado de falar e comer, a poetisa Stela do Patrocínio. Negra, "solteira, doméstica, de instrução secundária”, encontrava-se internada desde 1962. Seu ingresso se deu por condução da Quarta Delegacia de Polícia da cidade do Rio de Janeiro. O diagnóstico era de personalidade psicopática mais esquizofrenia hebefrênica, evoluindo sob reações psicóticas. Em 1966, aos 25 anos, foi transferida para a Colônia Juliano Moreira. No diário de Maura Lopes Cançado (1991), a Colônia é usada pelas guardas como ameaça para amedrontar e controlar as internas. Era o lugar para onde mandavam os casos mais graves, "os verdadeiros loucos":

a colônia Juliano Moreira, para onde vão os casos incuráveis, é o terror das internadas. Ficam em Jacarepaguá e contam atrocidades acontecidas lá. Elas dizem que é preferível morrer. Cercada de matas espessa, as doentes fugitivas são comidas por animais ferozes, contam. 
Composta por vários hospitais - homens e mulheres - velhos, imundos, comida infame, camas sujas com percevejos e outros bichos, muitas doentes dormem no chão - sobretudo apanham muito. Não se faz tratamento nas doentes por se considerá-las irrecuperáveis. Várias aparecem grávidas, os pais das crianças são geralmente os próprios funcionários. (CANÇADO, 1991, p. 57)

O rótulo de esquizofrenia hebefrênica e o abandono inscritos na ficha de Stela do Patrocínio atestavam uma personalidade desorganizada, delirante, de discurso incoerente, superficialidade afetiva, tendência ao isolamento social e dificuldade de expressar emoções e sentimentos. Contrariando essas limitações, a sua voz poética e filosófica irrompeu durante uma oficina de artes plásticas, realizadas em 1986, no núcleo de mulheres da Colônia.

$\mathrm{Na}$ época, Patrocínio estava com 45 anos. Pouco era conhecido a respeito de seu passado e de seus laços familiares e afetivos. A sua voz trouxe à tona a memória da menina negra que compartilhava com a mãe a profissão de empregada doméstica, a exploração do seu trabalho, o abandono, as violências físicas e psicológicas e a loucura. Também a reflexão de que foi levada a contragosto para o hospício e que sua liberdade não foi reivindicada nem pelos patrões, nem pela família.

Nesse burilar de lembranças compartilhadas, envoltas ao delírio, ela marca a sua subjetividade ao falar sobre os seus sonhos, seus modos de ver o mundo, o quanto gosta de coca cola, de leite condensado, de biscoito de chocolate. Também visibiliza as violências sofridas no ambiente hospitalar - eletrochoques e fortes medicações que lhe fazem se sentir mal - e aquelas que vivenciou além dos muros: a objetificação do corpo, a solidão da mulher negra, a violência sexual. A palavra falada não só interpela os estereótipos construídos em relação à esquizofrenia como também afirma a sua individualidade, a sua diferença. Assim, pode-se ponderar que a palavra materializa a sua existência dentro de um espaço de isolamento e homogeneização de subjetividades. O falatório de Patrocínio se solidifica enquanto palavra-corpo.

A escritora Conceição Evaristo (2005), quando explica a origem de sua escrevivência a partir das memórias da infância, relata que o primeiro contato com a escrita remete à lembrança da mãe e a estratégia usada por ela com o intuito de conseguir um dia ensolarado para secar roupas em dias chuvosos: desenhava, com uma varinha, a imagem do sol no chão. A imagem do corpo da mãe se estendendo em corpo desenhado é exposta de modo a enfatizar a importância da materialidade contida no ato de escrever. Os traços representando o sol evidenciavam a situação de urgência que a impeliram a esse gesto: a mãe era lavadeira, sem o sol e as roupas secas não haveria como garantir o sustento da família. 
A representação da escrita como urgência e corpo, de certo modo, também é recorrente em Patrocínio. A precariedade material e psicológica e o pouco acesso à escrita, a impossibilitam de dar forma a sua existência nas folhas de papel disponibilizadas no ateliê. Todavia, faz uso da palavra pausada e lírica para visibilizar e dar concretude às suas singularidades. O falatório chamou tanto a atenção das organizadoras da oficina que foi gravado pela artista plástica Neli Gutmacher e seus estagiários, transcrito pela estagiária Mônica Ribeiro de Souza e publicado, com o auxílio da psicanalista e poeta Viviane Mosé, com o título Reino dos bichos e dos animais é o meu nome (2001), em referência à definição de hospício expressa por Patrocínio.

Patrocínio, assim como Lima Barreto, foi conduzida para o hospício pela polícia. Ao falar a respeito de como foi levada para lá, enfatiza que foi violentada fisicamente por um homem, em seguida levada para um Pronto Socorro, logo depois conduzida para o hospício sem o direito de saber para onde a estavam levando: "carreguem ela, mas não me disse pra onde, ela achou que tinha o direito de me governar na hora, me viu sozinha [...] eu fiquei, de repente, de repente, eu fiquei sozinha". O prenúncio da solidão e da destituição do direito à liberdade de ir e vir é exposto junto à constatação de que essa violência foi justificada socialmente por sua condição social - "estou aqui como indigente, sem família, vim pra cá, estou aqui como indigente, sem ter ninguém por mim, sem ter família e morando no hospital" (PATROCÍNIO, 2001, p. 49).

A indignação diante da condução coercitiva é tamanha que ressalta ter sido o hospital quem a deixou doente. Além de evidenciar que não estava naquele lugar por escolha, essa afirmação propicia a reflexão sobre os efeitos e as consequências dos medicamentos e tratamentos hospitalares. Realça que "não ia adoecer sozinha", que o remédio lhe faz passar mal e que decidiu não tomá-los: cospe-os fora.

Assim, a autoexpressão é um modo de denunciar as violências e angústias cotidianas e aquelas guardadas em sua memória. É uma forma de resistência à solidão e ao isolamento no qual se encontra. É também modo de ressignificar a maneira como os outros a olham e se autoafirmar "eu sou uma negra preta e crioula", ainda que inserida em um processo de subjetivação institucional que insiste em colocá-la como igual aos demais "esses que são iguaizinhos a mim/ mas que são diferentes da diferença entre nós” (PATROCÍNIO, 2001, p. $63)$.

É importante ressaltar que o ateliê e demais circunstâncias que viabilizaram o falatório de Stela do Patrocínio se inserem no projeto de reforma psiquiátrica difundidos nos anos de 1960 com o objetivo de abolir os castigos, os quartos-fortes, os eletrochoques, a lobotomia e 
demais violências. A liberdade de existência e de expressão colocadas como tratamento terapêutico ofereceu a oportunidade para que Patrocínio pudesse falar e que sua voz transpusesse os muros do hospício.

É fato que, tal qual Lima Barreto, ela também faleceu antes da sua fala se tornar pública. Não viu que em 2002 o livro foi finalista do Prêmio Jabuti. Também não viu que em 2005 sua fala foi transformada em ópera pelo compositor Lincoln Antonio e que mais tarde foi encenada no espetáculo do Entrevista com Stela Patrocinio, de Georgette Fadel, Lincoln Antonio e Juliana Amaral ${ }^{3}$. A literatura, a arte, não a salvou do isolamento, não a tirou do hospício. Entretanto, o falatório, atravessado pelo delírio, ressoa na contemporaneidade a fala do(a) louco(a) silenciada pelo discurso racional. Ouvida por aqueles(as) que ousam pensar um tratamento terapêutico e humanizado, sem muros e violências, a sua voz continua a ressoar.

\section{Por que escrever? Por que falar?}

Se a expressão artística pode não ser o suficiente para salvar a própria vida do isolamento ou da subalternidade, por que continuar escrevendo e expondo opressões sociais?

Em certo ponto do falatório de Stela do Patrocínio, em meio a toda a visibilidade que a palavra falada conferiu a sua existência, ela questiona os limites do dizer, a inutilidade de continuar falando quando se sabe que a voz do(a) louco(a) dificilmente ultrapassa os muros do hospício: eu já não tenho mais voz/ Porque já falei tudo o que tinha que falar/ Falo, falo, falo, falo o tempo todo/ E é como se eu não tivesse falado nada" (PATROCÍNIO, 2001, p. 49).

Essa estratégia de silenciamento e deslegitimação da autorrepresentação do(a) louco(a) também é percebida em Lima Barreto. Ao caracterizar o hospício como lugar de abandono, esquecimento e segregação, o narrador-personagem lembra de uma informação lida sobre os cemitérios dos vivos na China, narrados por um diplomata brasileiro, e conclui que o hospício é "um lugar apropriado de domínio público reservado aos indigentes que se sentiam morrer. Dava-se-lhes comida, roupa e o caixão fúnebre em que se deviam enterrar" (BARRETO, 2009[1956], p. 80). Os muros que separam a loucura da sanidade, então, representam o isolamento, o silêncio e os obstáculos construídos para impedir a propagação dos gritos dos(as) loucos(as).

Talvez por isso Maura Lopes Cançado (2011 [1968], p.55), após ponderar a situação privilegiada garantida por ser escritora e trabalhar em um jornal, afirme a importância de sua

\footnotetext{
${ }^{3}$ Mais informações sobre o espetáculo podem ser encontradas no site https://entrevistacomstela.wordpress.com. Acesso em agosto de 2017.
} 
escrita para visibilizar as violências presenciadas no hospício: "só quem passa anonimamente por este lugar pode conhecê-lo. Afinal de contas, como analisa no conto "No quadrado de Joana", da coletânea $O$ sofredor do ver (1968), o(a) louco(a) é aquele(a) que está "à espera da forma de expressão: uma nova linguagem" com a qual possa expressar suas angústias e temores. Uma nova forma de linguagem com a qual, mesmo diante do desmoronamento e da impossibilidade de se enquadrar no modelo instituído, possa expressar-se.

Stela do Patrocínio (2001), a exemplo da personagem Joana, desmorona diante da impossibilidade de ser compreendida, de sequer ser ouvida: "me transformei com esse falatório todinho / Num homem feio/ Mas tão feio/ Que não me aguento mais de tanta feiura". É quando se coloca frente a essas amarras que constata que "quem vence o belo é o belo/ quem vence a saúde é outra saúde/ quem vence o normal é outro normal/ quem vence um cientista é outro cientista" (PATROCÍNIO, 2001, p. 142). Pensando assim, então, que vence a razão é outra razão. Daí a importância da intermediação intelectual para que vozes como a dela sejam ouvidas. Intermediar, como já observado em Spivak (2010) não é falar por, é tornar possível espaços onde o subalterno possa falar por si mesmo.

Não por acaso, as vozes de Lima Barreto, de Maura Lopes Cançado, da própria Stela do Patrocínio transcenderam os limites simbólicos e físicos manicomiais porque foram agenciadas por sujeitos privilegiados socialmente. Alguém o(as) ouviu e levou suas expressões para além das fronteiras hospitalares. É necessário salientar, entretanto, a importância da insistência em continuar falando presente nas obras desse(as) artistas: não fosse ela, tudo continuaria em silêncio no cemitério dos vivos. A vista disso, a necessidade de continuar dizendo, ainda que esse dizer seja rotulado como militante, chato, feio, ou mesmo segregado em nichos por serem considerados inferiores e menores pelo discurso dominante. Continua-se a dizer na esperança de que alguém do outro lado possa ouvir e, por conseguinte, estenda um pouco mais o alcance da voz. Insiste-se em falar para que outros iguais, num futuro breve, possam ser legitimados e tenham o direito à liberdade autorrepresentativa sem necessitar mais dessa intermediação.

Por fim, é importante lembrar que a visibilidade dessas perpassa por políticas públicas em prol da humanização do tratamento psiquiátrico e da luta antimanicomial. Em um momento de constantes ataques aos direitos das minorias, é imprescindível a participação de intelectuais e artistas na luta em defesa da democracia brasileira. Afinal, como dizia Sartre (2015, p. 58), “a liberdade do escrever implica a liberdade do cidadão. Não se escreve para escravos. A arte da prosa é solidária com o único regime onde a prosa conserva um sentido: a democracia. Quando uma é ameaçada, a outra também é”. Para que essas vozes dissonantes 
continuem a incomodar o sono injusto dos senhores da casa grande (EVARISTO, 2015, p. 3), a defesa da democracia deve ser prioridade.

\section{Referências}

ARBEX, Daniela. Holocausto brasileiro. São Paulo: Geração Editorial, 2013.

BARRETO, Lima. (2009) [1956]. O cemitério dos vivos. Virtual books. Disponível em: < http://bit.ly/2fwOF7A >. Acesso em 02 ago. 2017.

. Lima Barreto no Hospício. Entrevista. Jornal A Folha, 31 de jan. de 1920, Rio de Janeiro, 1920.

CANÇADO, Maura Lopes. Hospício é Deus: diário I. São Paulo: Círculo do livro, 1991 [1965], $189 \mathrm{p}$.

(2011) [1968]. O sofredor do ver. Brasília, Confraria dos bibliófilos do Brasil. Edições da Confraria 2011.

1968.

. (1968). Quem é Maura Lopes Cançado? a vida pela arte. Revista Leitura, n. 110, dez.

DALCASTANÈ, Regina. Literatura brasileira contemporânea: um território contestado. Vinhedo, Editora Horizonte/ Rio de Janeiro, Editora da Uerj, 2012.

EM NOME da razão. Direção: Helvécio Hatton. Produção: Tarcísio Vidigal. Documentário, 23'50', Belo Horizonte, Quimera Filmes LTDA, 1979. Disponível em: < http://www.dailymotion.com/video/x247d5a_em-nome-da-razao-um-filme-sobre-os-poroesda-loucura-1979_shortfilms>. Acesso em 25 jul. 2017.

EVARISTO, Conceição. Da grafia-desenho de minha mãe um dos lugares de nascimento de minha escrita. Rio de Janeiro, agosto de 2005. Disponível em < file:///C:/Users/ROSE/Downloads/DA\%20GRAFIA.pdf > Acesso em 15 de jul. de 2017.

FOUCAULT, Michel. Vigiar e Punir. Petrópolis: Editora Vozes, 1975.

. A história da loucura na Idade Clássica. Rio de Janeiro: Perspectiva, 1995.

Os anormais: curso no Collège de France (1974-1975). Trad. de Eduardo Brandão. São Paulo: Martins Fontes, 2001.

Problematização do sujeito: psicologia, psiquiatria e psicanálise. Trad. de Vera Lúcia Avellar Ribeiro. Manoel Barros da Motta (org.). 2. ed. Rio de Janeiro: Forense Universitária, 2002.

. História da Sexualidade: A Vontade de Saber. Rio de Janeiro: Graal, 1988. 
(2006) [2004]. A escrita de si. In: Ditos e escritos: ética, sexualidade, política. Organização e seleção de textos: Manoel Barros da Motta. Trad. de Elisa Monteiro, Inês Autran Dourado Barbosa. 2. ed. Rio de Janeiro: Forense Universitária, v. 5, p. p. 144-162

GOFFMAN, Erving. Manicômios, prisões e conventos. Trad. de Dante Moreira Leite. 7 ed. São Paulo: Perspectiva, 2001.

HIDALGO, Luciana; DRUMMOND Mônica (Orgs) (2006). A arte da Urgência. Curitiba: Cultural Office.

HIDALGO, Luciana. Literatura da urgência: Lima Barreto no domínio da loucura. São Paulo: Annablume, 2008.

Quando a loucura encontra a literatura: depoimento. [6 de novembro, 2008]. Rio de Janeiro. Boletim da FAPERJ. Entrevista concedida a Débora Motta. Disponível em< http://www.faperj.br/?id=1345.2.2> Acesso em: 13 ago. 2017.

SARTRE, Jean-Paul. Que é a literatura?. Tradução de Carlos Felipe Moisés. - Petrópolis, RJ: Vozes, 2015.

SPIVAK, Gayatri Chakravorty. Pode o subalterno falar? Trad. de Sandra Regina Goullart Almeida, Marcos Pereira Feitosa e André Pereira Feitosa. Belo Horizonte: Editora UFMG, 2010.

SHOWALTER, Elaine. The Female Malady: women, madness, and English Culture, 18301980. New York: Penguin Books, 1985. 